\title{
Architecture_MPS
}

\section{Property Market Deregulation and Informal Tenure in Egypt: A Diabolical Threat to Millions}

Yahia Shawkat ${ }^{1,2}$

How to cite: Shawkat, Y. 'Property Market Deregulation and Informal Tenure in Egypt: A Diabolical Threat to Millions.' Architecture_MPS, 2016, 9(1): 4. DOI: https://doi.org/10.14324/111.444.amps.2016v9i4.001.

Published: 01 June 2016

\section{Peer Review:}

This article has been peer reviewed through the journal's standard double blind peer-review, where both the reviewers and authors are anonymised during review.

\section{Copyright:}

(C) 2016, The Author(s). This is an Open Access article distributed under the terms of the Creative Commons Attribution License (CC-BY) 4.0 https://creativecommons.org/licenses/by/4.0/, which permits unrestricted use, distribution and reproduction in any medium, provided the original author and source are credited • DOI: https://doi.org/10.14324/111.444.amps.2016v9i4.001.

\section{Open Access:}

Architecture_MPS is a peer-reviewed open access journal. 


\title{
Amps
}

\section{Title: Property Market Deregulation and Informal Tenure in Egypt: A Diabolical Threat to Millions}

\section{Author: Yahia Shawkat}

\section{Architecture_media_politics_society. vol.9, no. 4.}

June 2016

Affiliation: 10 Tooba | Applied Research On The Built Environment \& EIPR*

\begin{abstract}
In the ambiguous legislative climate synonymous with authoritarianism, the Egyptian state has encouraged the commodification of land and property through a raft of different policies that have deregulated the market, driving up the prices in some places sixteen-fold over the last decade alone. State-led commodification in tandem with informal tenure for most Egyptians has meant the exploitation of many communities by a plethora of government and quasi-government agencies that claim their land as their own.

Through three different tenure cases lodged by the Egyptian Initiative for Personal Rights (EIPR) over the last four years, this paper will show how a pattern exists between state-led commodification and informal/insecure tenure. The case studies show the official use of direct methods of eviction such as eviction orders, sequestration decrees, and the falsifying of contracts. In addition, unofficial indirect methods of forced eviction have been used, such as cutting off power and water supplies, as well as the intimidation and torture of some residents.
\end{abstract}

The paper will also show how many of the forced evictions have happened, or been attempted, in the shadow of seemingly social motives like "upgrading unsafe areas," "the public good," or simply labelling the residents as "usurpers" and "squatters."

\footnotetext{
*This research is a collaboration between 10 Tooba | Applied Research on the Built Environment, where the author is Co-founder and Research Coordinator, and the Egyptian Initiative for Personal Rights (EIPR). The paper would not have been possible without the primary case work by EIPR's Hamdi Khalaf, Muhammad al-Kashef, Samoeil Tharwat, Ahmed Hossam and Manar Kamel.
}

DOI: 10.14324/111.444.amps.2016v9i4.001, ( $)$ 2016, The Author. This is an Open Access article distributed under the terms of the Creative Commons Attribution Licence, which permits unrestricted use, distribution, and reproduction in any medium, provided the original author and source are credited. 


\title{
Title: Property Market Deregulation and Informal Tenure in Egypt: A Diabolical Threat to Millions
}

\author{
Author: Yahia Shawkat
}

Architecture_media_politics_society. vol. 9, no. 4.

June 2016

\section{Roots of Informal/Insecure Tenure: A Legal Labyrinth}

A 1997 study revealed that 92\% of property in Egypt is unregistered, and most of this could never be registered as a consequence of decades of informality. ${ }^{1}$ Formal legal tenure was not sought in most cases because of complex and protracted steps to register property, which could include seventyseven bureaucratic procedures and take between six and fourteen years to complete. ${ }^{2}$ The study also identified a staggering nine typologies of tenure and divided them into two groups: buildings of informal origin and, more intriguingly, buildings of formal origin (Fig. 1).

While some claim that not all of the residents living informally are at constant risk of being evicted, as complicity between residents and key officials has bought some amnesty, ${ }^{3}$ informal tenure has made it easy for government agencies to evict residents from a property whenever deemed necessary and where public backlash would be minimal. It is estimated that over 42,000 families have been subject to relocation in Egypt over the last fifteen years due to so-called urban upgrading projects alone. ${ }^{4} \mathrm{~A}$ large portion of these relocations amount to forced eviction, as little or no consultation took place, while over half have been relocated to housing outside the city. ${ }^{5}$ These statistics do not include other forms of eviction, such as those related to expropriation orders, squatting on state-owned land, and the falling of original formal tenure into informality due to a number of factors including inheritance complications, changes in the law, or illegal transactions.

All three cases in this study represent tenure that started out formally and legally, but is now considered informal (see Table 1).

In Ramlet Bulaq residents have squatted uncontested for more than seventy years. ${ }^{6}$ Common Law allows for the possession of private land if it has not been contested in fifteen years, ${ }^{7}$ in this case land belonging to the industrial Kafrawy and 'Ezawy families. However, the squatters never took 


\section{Amps}

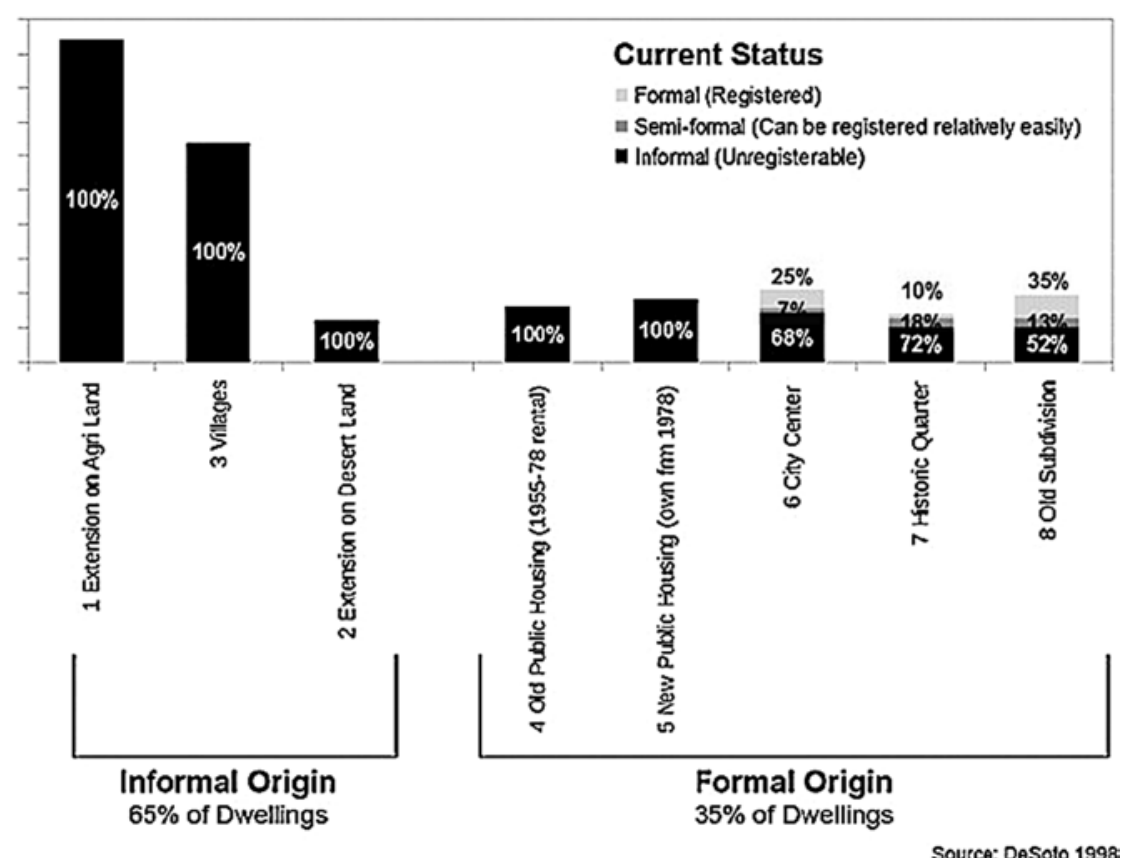

Figure 1. Typologies of informal tenure in Egypt according to DeSoto

their tenancy to court to formalise it, possibly because of the lack of belief in a court system that would cost them time and money they do not have, with a strong possibility that it would never be resolved. ${ }^{8}$ Indeed if straightforward registration of formal property takes an average of ten years to complete, how long would informal tenure take?

The farmers of 'Ezbet al-'Arab were given the right to own their land through the agrarian reform policies in the Arab Socialist era of the 1950s which nationalized large private land holdings, including that of the Awqaf (Religious Endowments). ${ }^{9}$ The Agrarian Reform Agency (ARA) redistributed the Khedieve's Ismail Waqf in Alexandria to smallholders, registering most of the land with the Real Estate Tax Registry, though part of it was not fully registered. ${ }^{10}$ Within a decade the Awqaf was re-established, and law 80/1971 stated that the ARA should reassign all land back to it. Two years later, law $42 / 1973$ amended that provision by stating that only land that was not redistributed to smallholders would be reassigned back to the Awqaf. However, the Awqaf ignored the 1973 amendment and brought most of the Ismail Waqf back under its de facto jurisdiction. In 1975 it revoked most farmers' ARA rent-to-own contracts and made out fixed term rental contracts. ${ }^{11}$

Employees of the state-owned Misr Spinning and Weaving Company (MSWC) received a small house or apartment in Mota'maret al-Mahalla funded through a profit- sharing scheme introduced in the 1950s during 


\section{Amps}

Table 1. Overview of the three Communities Covered in this Study

\begin{tabular}{|c|c|c|c|}
\hline Communities & Ramlet Bulaq, Cairo & $\begin{array}{l}\text { 'Ezbet al-'Arab, } \\
\text { Alexandria }\end{array}$ & $\begin{array}{l}\text { Mota'maret } \\
\text { al-Mahalla, } \\
\text { al-Gharbeyya }\end{array}$ \\
\hline $\begin{array}{l}\text { Number of } \\
\text { families }\end{array}$ & $500+$ & $234+$ & $750+$ \\
\hline $\begin{array}{l}\text { Hostile state } \\
\text { agencies }\end{array}$ & $\begin{array}{l}\text { Cairo Governorate, } \\
\text { Informal Settlements } \\
\text { Development Facility } \\
\text { (ISDF) }\end{array}$ & $\begin{array}{l}\text { Al-Awqaf, Alexandria } \\
\text { Governorate, } \\
\text { Agrarian } \\
\text { Reform Agency } \\
\text { (ARA), housing } \\
\text { cooperatives for state- } \\
\text { run agencies }\end{array}$ & $\begin{array}{l}\text { Misr Spinning } \\
\text { and Weaving } \\
\text { Co. (MSWC), } \\
\text { Gharbeyya Gov. }\end{array}$ \\
\hline $\begin{array}{l}\text { Residents' } \\
\text { claim }\end{array}$ & $\begin{array}{l}\text { Legal though } \\
\text { unformalised } \\
\text { squatting for over } \\
\text { ninety years on } \\
\text { private land of } \\
\text { absentee landlord. }\end{array}$ & $\begin{array}{l}\text { Majority rent } \\
\text { contracts with de } \\
\text { facto landlord, the } \\
\text { Awqaf. } \\
\text { Minority private } \\
\text { ownership after } \\
\text { completing lease-to- } \\
\text { own contract with the } \\
\text { de jure landlord the } \\
\text { ARA }\end{array}$ & $\begin{array}{l}\text { Shared ownership of } \\
\text { units that were built } \\
\text { using the MSWC } \\
\text { Workers' Housing } \\
\text { Fund on land owned } \\
\text { by the Gharbeyya } \\
\text { government in } \\
\text { agreement. }\end{array}$ \\
\hline $\begin{array}{l}\text { Area of } \\
\text { land }\left(\mathbf{m}^{2}\right)\end{array}$ & 29,000 & $1,629,600$ & 281,400 \\
\hline $\begin{array}{l}\text { Estimated } \\
\text { land value } \\
\text { (US\$ mn) }\end{array}$ & 170 & 1,058 & 263 \\
\hline
\end{tabular}

Arab Socialist reforms, where a portion of the worker's dividends would go to a housing fund. ${ }^{12}$ Once an employee was pensioned off, the MSWC would issue an eviction order which the employee would present to the local council and receive a council flat on a rent-to-own basis, jointly funded by the workers' fund and the Gharbeyya Governorate. However, the MSWC claimed in the late 1990s that the housing fund had been depleted, and today 750 retired workers and their families who received eviction orders do not have alternative housing and have continued to occupy the workers' units. The MSWC has considered these residents as squatters and continued to file eviction orders and the courts continued to uphold them despite evidence being given that there is no alternative housing and ignoring any claim that the housing was in fact a shared ownership scheme and not owned by the MSWC. ${ }^{13}$ 


\section{Amps}

\section{Asset Management of State-Owned Agencies and a Deregulated Property Market}

In 1958 the state established two distinct types of public land: public state land and private state land, allowing state-owned agencies to trade and deal in the latter. ${ }^{14}$ This was at a time of Arab Socialism where the state owned businesses, and these businesses were allowed to trade and deal in public land. And so the law established that any vacant land in Egypt that has no legal owners, state or private, will be considered a national resource owned by the state and thus considered private state land.

This law had a number of consequences that would lay the groundwork for the three cases presented in this paper. The first was that it prohibited any adverse possession, traditional claims or otherwise, of land; thus, even though communities had put vacant land to use by squatting on it for decades, their claim would not be recognised if they squatted after 1942 (fifteen years prior to the new law), or had no documents to prove it.

Another consequence of the law was that publicly owned companies and agencies could sell state land under their jurisdiction to generate revenues for themselves, as private state land was considered an economic asset and could be sold, while public state land - mainly roads and canals - are considered public domain and cannot be sold.

With the shift from Arab Socialism to Neoliberalism in the second half of the 1970s, along with the fact that the Egyptian government is the country's largest landowner through various state-owned agencies, government policy has constantly worked towards deregulating the property market in favour of driving land and property prices up, and thus boosting revenue for the state. Deregulation wasn't a side-effect or a matter of neglect but "a conscious decision by authorities," as lawyer and urban planner Peter Marcuse points out. ${ }^{15}$

A second shift towards further deregulation happened in 1996 when the government started a process of allowing foreign individuals and businesses to buy land and property in Egypt, where law 230/1996 was passed annulling the very restrictive law 56/1988, though it also stipulated a number of limitations including a maximum limit of two units not exceeding 4,000 meters each. It seems the new limitations were still too restrictive, so Prime Ministerial decree 248/2005 removed limitations on area and number of units in certain geographic areas - mainly the coastal tourism zones on the Mediterranean and Red Seas.

Encouraged by the revenue of land sales on the coasts, where one auction netted 1 billion EGP alone, ${ }^{16}$ a milestone then, a further amendment in 2007 removed almost all geographic restrictions on foreign landownership bar Sinai. ${ }^{17}$ Almost overnight, land prices spiked $116 \%$ in the suburb-like "New Cities" around Cairo, with a staggering average annual increase of $148 \%$ between 2003 and 2013. ${ }^{18}$ For FY 2015/2016, the New Urban Communities Authority (NUCA), the largest of Egypt's urban landholders and which owns 


\section{Amps}

and administers these so-called New Cities, announced it would generate EGP 50bn (US\$ 5.9bn) from land sales alone. ${ }^{19}$

While NUCA has been assigned mostly vacant state-owned desert land with the sole purpose of developing it, other state-owned enterprises that should be doing something else - managing local services, cultivating agricultural land, or (shock-horror) manufacturing products - have sought to monetise land they claim jurisdiction over, land that is home to millions of Egyptians. Spurred on by the 1990s IMF and World Bank structural adjustment policies, these agencies have gone on an 'asset management' spree in order to raise their value before being privatised, or used as collateral towards loans.

With the state budget deficit surging past $10 \%$, in arguably one of its most concerted asset management moves to buttress state spending, the cabinet quietly established the Committee to Inventory Unused State Assets last October to "build a database of unused assets belonging to ministries, local government and the agencies affiliated with them, and establish a plan to utilise them in a manner that would realise the highest possible return." 20 The committee emerged at a time when many government agencies had already started building databases of their own, including the Ministry of Water Resources, ${ }^{21}$ local governments such as Minya, ${ }^{22}$ or governmentowned agencies such as the state-run Egyptian Radio and Television Union (ERTU) whose main headquarters is in a prime area overlooking the Nile in Cairo. $^{23}$

Many state-owned companies now even have their own real estate investment divisions to capitalise on their large landholdings or are in the process of setting them up. These include all the subsidiary companies within the Holding Company for Silos, Mills and Bakeries, ${ }^{24}$ Egypt National Railways' ERJET, which identified over 45,000 acres that it seeks to "re-utilise," 25 generating EGP 400mn this year alone, ${ }^{26}$ and the Agricultural Development and Lending Bank which controls EGP 4bn worth of assets. ${ }^{27}$ The World Bank has played a role in setting up some of these companies, while it has asked outright for a full inventory of all land under the jurisdiction of the Cairo Transport Authority (CTA) as a prerequisite for disbursing a loan. ${ }^{28}$

In the government's desperation to raise cash, asset management has taken an even more sinister curve. An amendment to the ERTU's by-law proposed by the Ministry of Planning would change the type of state land under the agency's jurisdiction from public state land, since it was never a holding company, to private state land, where it could be sold on to private investors. ${ }^{29}$ Such a change is unprecedented, and if passed would be the first realization of the 2014 constitution which deleted the stipulation that described the public role of land, a realization that would allow virtually all land designated for public use, or expropriated for public benefit, to be sold off to investor/speculators. 


\section{Amps}

\section{Asset-Management and Informal Tenure: Exploiting the Rent Gap}

With the selling off of a considerable portion of state-administered assets, especially assets with vague legal tenure and located in so-called prime areas of the city, the threat of forced eviction for millions looms large.

The Cairo 2050/2052 plan to gentrify the more lucrative parts of Cairo, drawn up by the General Organisation for Physical Planning (GOPP) and Cairo Governorate, sought to capitalize on the state-induced property boom of the 2000s, where land prices of so-called prime locations on the riverfront in the heart of Cairo went up $44 \%$ a year over a decade. ${ }^{30}$ The Urban Development Plan for Rod al-Farag, ${ }^{31}$ part of the Cairo 2050/2052 plan, included the "demolition of unsafe shacks" and the relocation of residents in three "slum nodes" including "Ashwaeyat Nile Towers (i.e. Ramlet Bulaq) to housing estates in the New Cities outside Cairo or paying them compensation (Fig. 2). ${ }^{32}$ According to a former head of the Informal Settlements Development Facility (ISDF), the Ramlet Bulaq project could net them EGP 600mn (US\$ 71mn). ${ }^{33}$

As urban development spread informally over green field sites, large portions of Awqaf administered agricultural land became prime land for real estate development, making the eviction of farmers and the developing or selling off the land lucrative. Farmers in 'Ezbet al-'Arab typically rent out an acre for EGP 2,000 (US\$ 236) per year, netting the Awqaf a mere EGP 600,000 (US\$ 71,000) from the 300 acre Muthalath parcel it does not legally own. In a dubious profit-sharing scheme between the Awqaf and the Alexandria Governorate, ${ }^{34}$ the latter would receive a third of the Muthalath

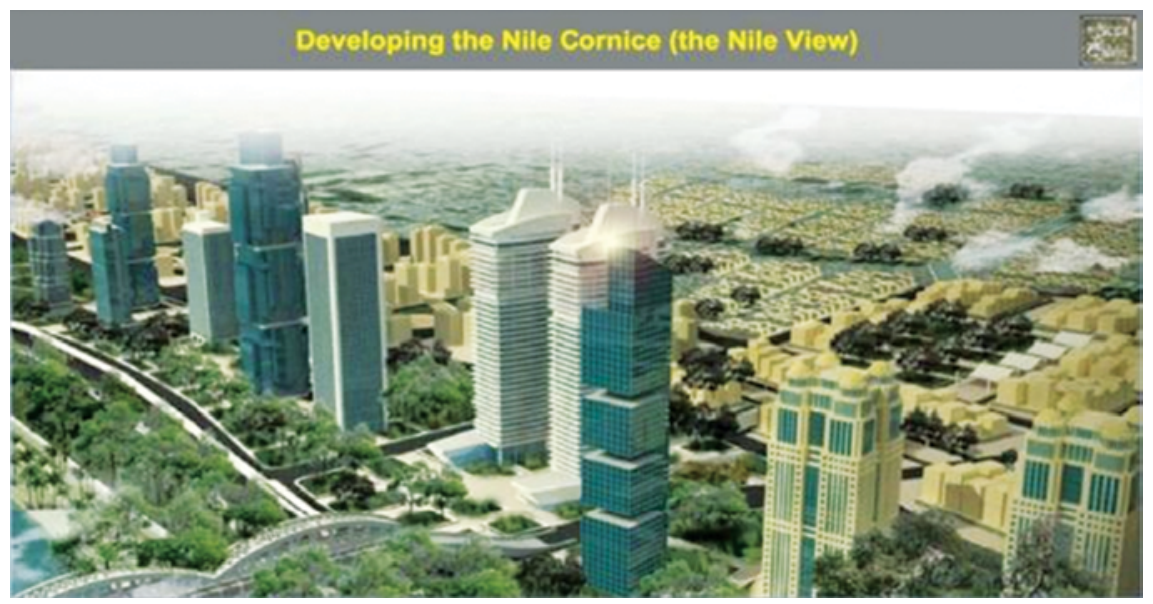

Figure 2. Rendering of the Rod al-Farag Corniche in the Cairo 2050 Plan. Only the identical Nile City Towers on the right exist, behind them is Ramlet Bulaq.

Source: GOPP 


\section{Amps}

in exchange for reassigning the land as part of the city limits, evicting the residents, demolishing any buildings on the land, and servicing the new subdivisions with infrastructure (Fig. 3), while the Awqaf stood to make EGP 6bn (US\$ 706mn). ${ }^{35}$ The Awqaf has inventoried all of its land and recently was set to boost state revenue by selling off assets worth EGP 1.2bn (US\$ 141mn) in one auction alone. ${ }^{36}$

Ever since law 203/1991 came in on the back of structural adjustment policies pushed through by the IMF and World Bank, the government has been trying to privatize state-owned companies, sometimes at bargain rates. The first attempt to privatize the MSWC in 2004 failed, as workers protested. ${ }^{37} \mathrm{~A}$ decline in production and a rise in debt, brought on by a lack of investment in the company, have recently led the Holding Company for Cotton Spinning and Weaving, which owns MSWC, to boost revenue through international restructuring consultants and inventorying its assets. ${ }^{38}$ Privatizing MSWC with hundreds of people living on its assets is not the best way to go, which may explain why it has demolished the homes it has been able to vacate as opposed to reassigning them to new employees (Fig. 3). But if MSWC doesn't own the land, how would it profit? In 2009 a planned joint development emerged in the press that MSWC and the Gharbeyya Governorate will build a 5448-unit commercial housing project in place of the Mosta'mara, ${ }^{39} \mathrm{a}$ scheme that could be valued at EGP 1.6bn (US\$ 188mn).

In all three communities, there was a considerable "rent-gap" between what it would cost the agencies to evict the residents and the market value

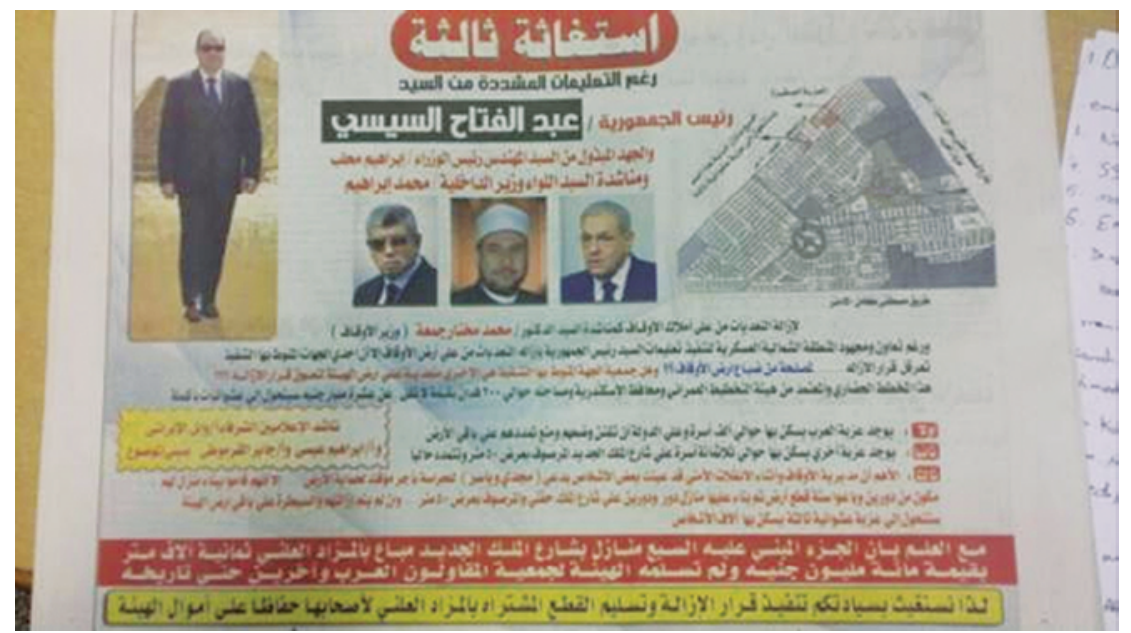

Figure 3. Front-page ad published by the Awqaf calls for the intervention of the president in evicting the residents of some land plots in Muthalath al-Monntazah. At the top right is an image of the proposed urban subdivision plan.

Al-Gumhureyya, November 11, 2014. 


\section{Amps}

60,000
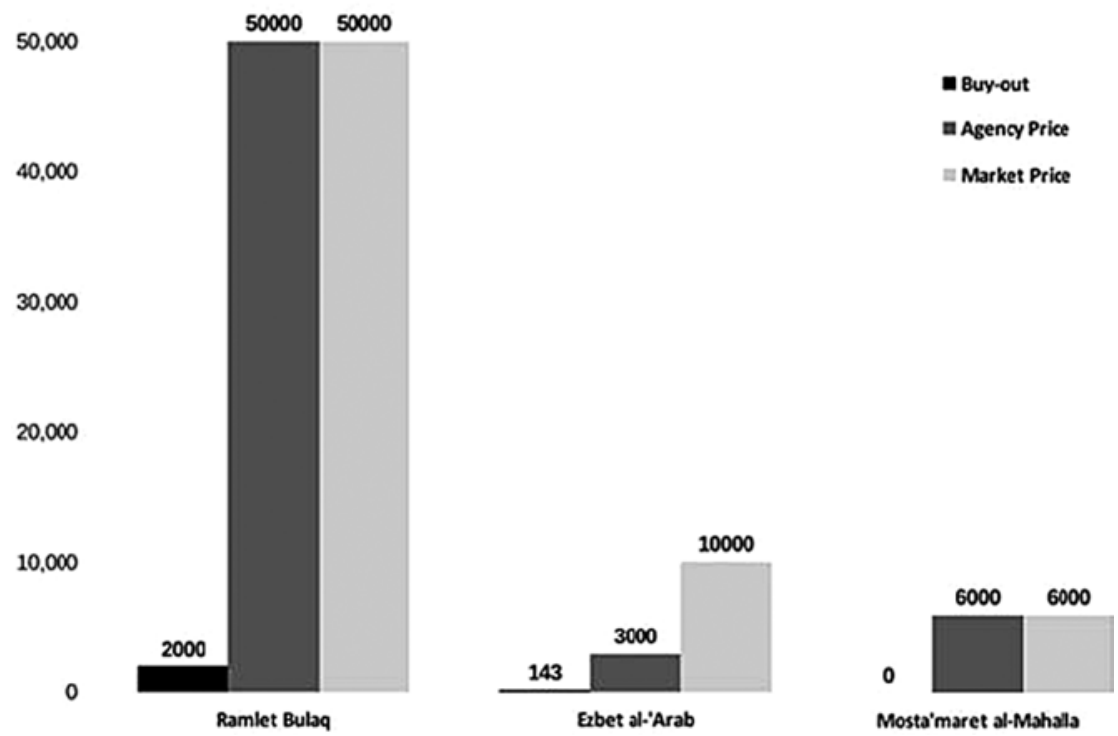

Figure 4. Rent-gap between what the government agencies may pay to buy out residents, the values they may sell the land on to private investors, and the estimated market value of the land. $\left(\mathrm{EGP} / \mathrm{m}^{2}\right)$

of the land, a gap only possible because of the situation of informal tenure (Fig. 4). Officials in some negotiations with the residents of Ramlet Bulaq offered to pay them what would amount to EGP 2,000 per square meter, compared with the EGP 50,000 reported market value. ${ }^{40}$ In Muthalath alMontazah some residents accepted to sell their land for EGP 143 per meter, even though the Awqaf had sold similar plots at auction for EGP 3,000 per meter. ${ }^{41}$ Intriguingly, real estate developers operating in the area sell land for about EGP 10,000 per meter, leading to assumptions that some auctions by government agencies are rigged to be under-valued in favour of the private developers that buy land from them.

\section{Mechanisms of Eviction: Writing Your Own Rule-Book}

In all three cases, state agencies have used legal methods to evict, or attempt to evict, residents even though they had weak or no grounds to do so.

When the ISDF was set up in 2009 an amendment to the Expropriation Law 10/1990 was made allowing private land to be expropriated if it was deemed by the ISDF to be an unsafe area: the residents were in danger of natural disasters, building collapse, pollution, or insecure tenure. ${ }^{42}$ If the 


\section{Amps}

community was on state-owned land a simple eviction order could be issued. The ISDF also produced the National Map of "Unsafe" Areas that identified over 212,000 families living in such areas, 120,000 of which live informally on state-owned land. ${ }^{43}$ This policy seems to have been written for any governor wishing to get rid of shack dwellers, where a simple eviction order could be issued if the community was on state-owned land, or an expropriation decree would be issued if it was on private land.

The Cairo Governor did the latter when he issued temporary expropriation decree $8993 / 2011$, basing it on a report by the ISDF that classified Ramlet Bulaq as a "Level 2 unsafe area." Had it not been for a keen-eyed lawyer who noticed the sequestration decree in the official gazette, an appeal would not have been lodged. ${ }^{44}$ The appeal was eventually won, mostly on technical grounds where the Cairo Governorate was found to not have completed the formal steps to sequester the land. ${ }^{45} \mathrm{Had}$ they done so, it would have been very hard for the appeal to have been won.

For both the Mosta'mara and the 'Ezbet al-'Arab cases, the MSWC and the Awqaf simply exploited vague or contradictory legislation. The MSWC benefitted from complacent district courts, complex tenure arrangements with the Gahrbeyya Governorate and missing information tying the workers' housing fund to the flats. The Awqaf seems to have relied more on either a complacent or a complicit ARA which did not fully register the redistributed smallholdings in the 1960s, as well as exploiting the many layers of legislative amendments that govern land reform.

In all three cases, slow and long-acting indirect methods of eviction were used to weaken the communities as the legal cases were not strong. The Cairo Governorate has long banned the installation of water and waste water networks in the Ramla, citing it as an informal area. ${ }^{46}$ In the Mosta'mara, the MSWC has refused to repair old water piping that has polluted the drinking water, forcing residents to use a well that a charity built instead (Fig. 5). ${ }^{47}$ In 'Ezbet al-'Arab farmers allege that the Awqaf filled in a canal as well as diverted raw sewage to a number of land parcels, ruining the existing crops and any chance of new crops growing. ${ }^{48}$

When direct legal actions were not enough to evict the residents, mostly when residents were able to successfully challenge the cases in court, or when they physically resisted, and the indirect actions did not have the effect they wanted, the government agencies resorted to intimidation and violence, through accomplices from outside the agencies.

The Nile City towers adjacent to Ramlet Bulaq were the scene of a crime where a police officer stationed there shot and killed an unarmed resident of Ramlet Bulaq, inciting riots that ended in the mass arrest of fifty-one men from the area in a dawn raid. ${ }^{49}$ The court ruling annulling the expropriation order of Ramlet Bulaq cited a number of incidents that had been used since 1997 to terrorize the Ramlet Bulaq residents into selling out to the corporation that owns the adjacent luxury towers for unfairly low prices. ${ }^{50}$ These included how no investigation was opened into the shooting and killing of 


\section{Amps}

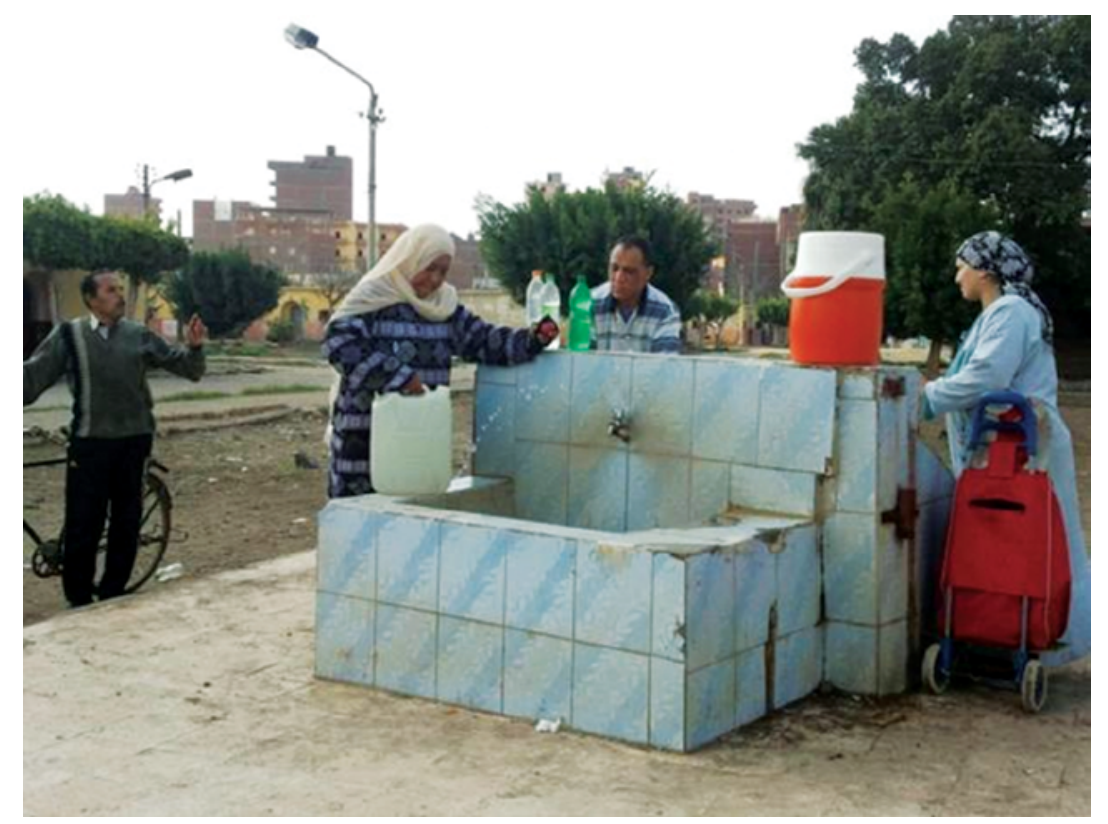

Figure 5. Mosta'amara residents using a communal tap. Yahia Shawkat

'Amr al-Boni by the police officer, as well as a number of recorded complaints made against another officer based at the towers for kidnapping children from Ramlet Bulaq and framing them for crimes they did not commit, leading the court to conclude that the Cairo Governorate has been complicit with the tower owners in attempting to evict the residents and use the land for commercial purposes.

In 'Ezbet al-'Arab the situation is just as dark. In 2009, Hassan Shindy, the leader of a cluster of families that protested the sale of their land by the Awqaf to a number of housing co-operatives set up by employees of state agencies, was found murdered in the fields, with a warning scribbled on his clothes. $^{51}$ The Awqaf made EGP $100 \mathrm{mn}$ from selling the farmers' plots from within the main Muthalath parcel and deeds found by lawyers investigating the case found out they were made to three housing co-operatives affiliated to the police. ${ }^{52}$ When even murder was not enough to terrorize the farmers off their land, the Awqaf is alleged to have rented out thugs to live in shacks on the land parcels and prevent the farmers from reopening the canal it had filled in to starve their crops. ${ }^{53}$

\section{Conclusion: A Manufactured Informality}

A pattern of methodical abuse, by the state and its agencies of legislation governing tenure, seems hard to ignore. The cases presented are but a sample 


\section{Amps}

of this abuse, which when scaled up to the respective agencies' reach would include a considerable portion of Egyptians. The Awqaf is landlord to 4,000 villages and hamlets, ${ }^{54}$ or about $15 \%$ of Egypt's rural communities where around $1.5 \mathrm{mn}$ families live. The ISDF has inventoried over 400 informal areas which are home to over 212,000 families, 120,000 of which are considered squatters on land owned by the state. ${ }^{55}$ The MSWC is one of almost 200 public-sector companies that are up for privatization and many of these own or administer employee housing.

At the same time, the government has been further institutionalizing and developing its asset management tools in a bid to plug an ever increasing budget deficit. A central database of land administered by the various government agencies, showing size, location, and value is possibly complete by now, as are plans to benefit from this land, whether by selling it off or going into partnerships with private investors with an equity share equal to the value of the land. Either way whatever exists on that land will be removed to make way for these new investments. As an executive which has historically played a strong role in legislation, ${ }^{56}$ the government looks to be setting new precedents in exploiting land it administers, and expanding its domain, such as by reassigning once public state land to private state land.

The current legislature, one that is heavily influenced by big business, ${ }^{57}$ will most probably support the government in selling off its assets - from the private investor's perspective, seeking to accelerate privatisation. Indeed, another round of privatisation seems to be set in motion, with key business men set to benefit. ${ }^{58}$

This diabolical mix of interests makes it almost impossible to foresee any steps to recognize the informal tenure of millions of Egyptians with legally vague tenure. In fact there is every incentive to perpetuate, expand, and exploit the informal status. ${ }^{59}$

\section{Notes}

1 Hernando DeSoto, Dead Capital and the Poor in Egypt (Cairo: ECES/ILD, 1998).

2 Ibid.

3 Marion Sejourne, "Inhabitants' Daily Practices to Obtain Legal Status for Their Homes and Security of Tenure: Egypt," in Popular Housing and Urban Land Tenure in the Middle East: Case Studies from Egypt, ed. Myriam Ababsa et al. (Cairo: American University in Cairo Press, 2012), 91-110.

4 Between 1997 and 2013, urban development plans resulted in the eviction and supposed resettlement of 24,126 families outside of the city, as well as the rehousing of 17,113 families in newly built housing in or close to their original place of residence. Yahia Shawkat, Al-'Adala al-Igtimaeya wal-'Omran; Kharitat Masr (Cairo: Shadow Ministry Of Housing, 2013), 83.

5 Ibid.

6 As per documents submitted to court showing tenancy of between fifty and seventy years. Egypt Adminstritave Court, "Circuit 4; Ruling on Case 55949/66," 2013. 


\section{Amps}

7 Art. 968 and 969, Common Law 131/1948.

8 Interview with Ahmed Hossam, case lawyer at EIPR, December 1, 2014.

9 Agrarian Reform Law 178/1952 and laws 152/1957 for general waqf and 44/1962 for private waqf.

10 ARA decree 30/1963, dated December 18, 1963. EIPR, 'Ezbet al-'Arab/ Muthalath al-Montazah, Internal Case Report (Cairo: EIPR, 2014).

11 Copy of a rent contract made out by the Awqaf to one of the farmers. Ibid.

12 Interview with Mohamed Wadi, head of the Mahalla Pensioners' Union, February 17, 2014. EIPR, Mosta'maret al-Mahalla, Internal Case Report (Cairo: EIPR, 2014).

13 Interview with EIPR lawyer, Samuel Tharwat, who represented thirtry-three of the families challenging eviction rulings, February 17, 2014. Ibid.

14 Law 147/1957 amending Article 970 of Common Law 131/1948.

15 Closing Conversation, City Debates 2015, American University of Beirut, June 3, 2015.

16 "Emaar Misr wins bid for Sidi Abdel Rahman Bay," Daily News Egypt, August 18, 2006, accessed March 28, 2016. http://www.masress.com/en/dailynews/103967.

17 Prime Ministerial Decree 350/2007.

18 Yahia Shawkat. "Egypt's Deregulated Property Market: A Crisis of Affordability." MEI, 052015.

19 New Urban Communities Authority,"Wazir al-Iskan: al-'Asema al-Idareyya al-Gadida Lan Tukalif al-Dawla Maliman Wahedan ... Wa Tarh Aradi Bi 50 Milyar Genieh al-'Am al-Muqbil”, 29.09.2014, Accessed: 07.01.2016 http://www. newcities.gov.eg/dispNews.aspx?ID=970

20 Prime Ministerial Decree 2589/2015

21 Al-Masry al-Youm. "Moghazy: Bid' hasr amlak al-ray fi al-muhafzat", Al-Masry al-Youm, March 3, 2015, accessed March 28, 2016. http://www.almasryalyoum. com/news/details/669418

22 "Muhafiz al-Minya: Hasr aradi amlak dawla wa tashkil lagna li-al-istikhdam al-amthal laha," Al-Shorouk, September 30, 2015, accessed March 28, 2016. http://www.shorouknews.com/news/view.aspx?cdate $=30092015 \mathrm{andid}=\mathrm{e} 4$ c1b572-8278-46ce-84e4-2a71ecf566d5.

23 "Al-Maleyya: lagna li hasr was taqyim aradi al-itha'a wal-television gheir al-mustaghalla," Al-Borsa News, August 25, 2014, accessed March 28, 2016. http:// tinyurl.com/jnrz4sm

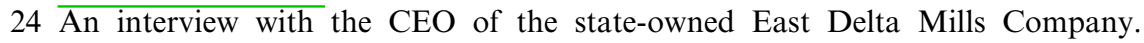
"Al-Matahin Turahin 'ala al-Istithmar al-'Aqari," Al-Mal, September 1, 2015, accessed January 8, 2016. http://www.almalnews.com/Pages/StoryDetails.aspx?ID $=244618 \#$.VeXlevyE aKA

25 "Wazir al-naql yusder qarar bi i'adet istighlal 190million metr lil-sikka al-hadid," Akhbar al-Youm, August 27, 2013, accessed March 28, 2016. http://tinyurl.com/ gmdkbo3

26 "Al-Masriyya tatrah mashru'at sakaneyya bi 400 million geneih," Al-Mal, December 15, 2015, accessed March 28, 2016. http://www.almalnews.com/Pages/ StoryDetails.aspx?ID=261259. 


\section{Amps}

27 "Al-i'teman al-zira'ey yutliq sharika li-ida al-osul. khilal shahrayn," Al-Mal, March 21, 2016, accessed March 28, 2016. http:/www.almalnews.com/Pages/ StoryDetails.aspx?ID=275573.

28 "Al-bank al-dawli yatlub hasran bi-aradi al-naql al'am qabl iqradiha 20 million dular," Al-Mal, February 10, 2013, accessed March 28, 2016. http://www. almalnews.com/Pages/StoryDetails.aspx?ID=34162.

29 "Infirad. al-hukuma tasmah li-maspero bi-be'a usulh li tasdid maduneyatuh wa amwal al-television tatahawal li milkeya khassa wa laysat milkan lil-dawla," Sada al-Balad, May 13, 2015, accessed March 28, 2016. http://www.el-balad. com/1531946.

30 According to Cairo Governor Galal Said, a land plot sold in 2005 for 8,000 Egyptian pounds $(\$ 1,050)$ per square meter was valued at 40,000 Egyptian pounds $(\$ 5,260)$ per square meter in 2014 . See "Al-Qahira tukhatit li-i'adit hekr abudoma lil-kharita al-istithmariyya lil-muhafaza," Al-Borsa News, August 26, 2014, accessed January 8, 2016. http://tinyurl.com/oc913tk.

31 Cairo Governor Decree 7901/2009.

32 "Wazir: Ligan li-Hasr al-'Aqarat Alati Tuskakel Khuturah 'ala Bulaq," Egypt News, January 2, 2011, accessed January 8, 2016. http://www.masress.com/ egynews/11 2015.

33 "Sanduk Tatwir al-'Ashwaeyat Yabda" Tatwir Ramlet Bulaq," Al-Borsa News, April 6, 2013, accessed January 7, 2016. http://tinyurl.com/zvrju3d.

34 Wizaret al-Awqaf - Muhafazet al-Iskandereyya, Protocol Ta'awon 3/696, 31.01.2008. Ministry of Awqaf Internal document. EIPR, 'Ezbet al-'Arab/Muthalath al-Montazah.

35 The Awqaf claimed the parcel was valued at "more than EGP 9bn" (US\$1.1bn) in a half-page ad it put out on the front page of a state-owned newspaper urging the Egyptian President to enact eviction orders on the Muthalath al-Motazah land parcel because the Alexandria Governorate was slow to act. "Istighatha Raqam Etnein," al-Gumhureyya, November 11, 2014. Also see Fig. 3.

36 "Al-Awqaf Tabe'a Usul bi qimat 1.2 Milyar Geneih fi Mazad 'Alani," Al-Mal, November 11, 2013, accessed January 5, 2016. http://www.almalnews.com/mobile/ Pages/StoryDetails.aspx?ID=116670.

37 Joel Beinin and Hossam El-Hamalawy, "Egyptian Textile Workers Confront the New Economic Order," MERIP, April 25, 2007.

38 "Cotton Spinningand Weaving to PumpEGP150m Investmentsinto 8 Subsidiaries," Daily News Egypt, September 13, 2015, accessed January 5, 2016. http://www. dailynewsegypt.com/2015/09/13/cotton-spinning-and-weaving-to-pump-egp$150 \mathrm{~m}$-investments-into-8-subsidiaries.

39 "Mufaga'a bil-mustanadat: Masakin madinat al-'ommal bil-mahalla al-kubra. amlak dawla!," Al-Ahram, November 23, 2009, accessed January 5,2016. http:// www.ahram.org.eg/Archive/2009/11/23/MHFZ1.HTM.

40 Interview with Ahmed Hossam, case lawyer at EIPR, December 1, 2014.

41 EIPR, 'Ezbet al-'Arab/Muthalath al-Montazah.

42 Prime Ministerial Decree 3096/2009.

43 ISDF, National Map of "Unsafe" Areas. Internal Report, 2011. 


\section{Amps}

44 EIPR was already representing thirty of the fifty young men arrested from Ramlet Bulaq, where Ahmed Hossam was familiar with the community, when he noticed the expropriation decree and brought it to the attention of the residents there. They were able to lodge an appeal and eventually won it. EIPR Press Release: “Al-Qada' al-Idari Yantasser li Ahali al-Ramla," August 28, 2013. http://eipr.org/ pressrelease/2013/08/28/1802.

45 Egypt Administrative Court, Ruling on Case 55949/66.

46 Shadow Ministry of Housing, "Badal Matshiluna, Tawaruna!" Short documentary, October 3, 2013. https://www.youtube.com/watch?v=qrIAReY7XUI.

47 Interview with Muhammed Wadi, February 17, 2014. EIPR, Mosta'maret al-Mahalla.

48 Interview with K.Y., a tenant of the Muthalath parcel, Alexandria, January 8, 2014. EIPR, 'Ezbet al-'Arab/Muthalath al-Montazah.

49 "EIPR Accuses Police Officer of Murder in Nile City Incident," Egypt Independent, August 16, 2012.

50 Egypt Administrative Court, Ruling on Case 55949/66.

51 "Maqtal Za'eem al-Falahin al-Rafidin li-Bee'a Aradihom bil-Muntazah," Al-Youm al-Sabe', September 23, 2009. http://www.youm7.com/story/0000/0/0//138702\#.VpA1O1J-z3U.

52 Copy of deeds made out in 2008 to the Amal Co-operative, its director a Major General, the Hossam Co-operative, headquartered in the Alexandria Security Directorate, and the Alexandria Investigative Police Co-operative. EIPR, 'Ezbet al-'Arab/Muthalath al-Montazah.

53 Interview with K.Y., Tenant of the Muthalath parcel, Alexandria, January 8, 2014. EIPR, 'Ezbet al-'Arab/Muthalath al-Montazah.

54 “Raeis Hay'et al-Awqaf fi Hiwar ma' al-Ahram: La Tasaluh ma' al-Muta'adi 'ala Mal al-Waqf," Al-Ahram, June 10, 2011, accessed January 7, 2016. http://www. ahram.org.eg/archive/Religious-thought/News/82855.aspx.

55 ISDF, National Map of Unsafe Areas 2011. Internal Report.

56 "Legislation Tracker: A Constitutional Perspective," TIMEP, n.d., accessed January 10, 2016. http://timep.org/legislationtracker.

57 "High-Profile Businessmen MPs to Play Big Role in Egypt's New Parliament: Analysts," Ahramonline, December 5, 2015, accessed January 10, 2016. http:// english.ahram.org.eg/NewsContent/1/164/172667/Egypt/Egypt-Elections-/ Highprofile-businessmen-MPs-to-play-big-role-in-Eg.aspx.

58 Ibrahim Alsahary, "Egypt's Wave of Privatisation: What does Sawiris Really Know?," The New Arab, February 8, 2016, accessed March 28, 2016. https:// www.alaraby.co.uk/english/Comment/2016/2/8/Egypts-wave-of-privatisationWhat-does-Sawiris-really-know.

59 Part of this research was conducted while the author was Housing and Land Rights Officer at the Egyptian Initiative for Personal Rights (EIPR), and would not have been possible without the primary case work by 'Hamdi Khalaf, Muhammad al-Kashef, Samoeil Tharwat, Ahmed Hossam, and Manar Kamel. 


\section{Amps}

\section{Bibliography}

Ahramonline. "High-Profile Businessmen MPs to Play Big Role in Egypt's New Parliament: Analysts," December 5, 2015. Accessed January 10, 2016. http:// english.ahram.org.eg/NewsContent/1/164/172667/Egypt/Egypt-Elections-/ Highprofile-businessmen-MPs-to-play-big-role-in.

Akhbar al-Youm. "Wazir al-naql yusder qarar bi i'adet istighlal 190million metr lilsikka al-hadid." August 27, 2013. Accessed March 28, 2016. http://tinyurl.com/ gmdkbo3.

Al-Ahram. "Mufaga'a bil-mustanadat: Masakin madinat al-'ommal bil-mahalla al-kubra.. amlak dawla!" November 23, 2009. Accessed January 5, 2016. http:// www.ahram.org.eg/Archive/2009/11/23/MHFZ1.HTM.

Al-Ahram. 'Raeis Hay'et al-Awqaf fi Hiwar ma' al-Ahram: La Tasaluh ma' al-Muta'adi 'ala Mal al-Waqf.” June 10, 2011. Accessed January 7, 2016. http:// www.ahram.org.eg/archive/Religious-thought/News/82855.aspx.

Al-Borsa News. "Al-Maleyya: lagna li hasr was taqyim aradi al-itha'a wal-television gheir al-mustaghalla.” August 25, 2014. Accessed March 28, 2016. http://tinyurl. com/jnrz4sm.

Al-Borsa News. "Sanduk Tatwir al-'Ashwaeyat Yabda' Tatwir Ramlet Bulaq." April 6, 2013. Accessed January 7, 2016. http://tinyurl.com/zvrju3d.

Al-Mal. "Al-Awqaf Tabe'a Usul bi qimat 1.2 Milyar Geneih fi Mazad 'Alani." November 11, 2013. Accessed January 5, 2016. http://www.almalnews.com/ mobile/Pages/StoryDetails.aspx?ID=116670.

Al- $\overline{M a l}$. "Al-bank al-dawli yatlub hasran bi-aradi al-naql al'am qabl iqradiha 20 million dular." February 10, 2013. Accessed March 28, 2016. http://www. almalnews.com/Pages/StoryDetails.aspx?ID=34162.

Al-Mal. "Al-i'teman al-zira'ey yutliq sharika li-ida Accessed al-osul.. khilal shahrayn."

March 24, 2016. Accessed March 28, 2016. http://www.almalnews.com/Pages/ StoryDetails.aspx?ID=275573.

Al-Mal. "Al-Masriyya tatrah mashru'at sakaneyya bi 400 million geneih." December 15, 2015. Accessed March 28, 2016. http://www.almalnews.com/Pages/ StoryDetails.aspx?ID=261259.

Al-Mal. “Al-Matahin Turahin 'ala al-Istithmar al-'Aqari.” September 1, 2015. Accessed January 8, 2016. http://www.almalnews.com/Pages/StoryDetails. aspx?ID=244618\#.VeXlevyE aKA.

Al-Masry al-Youm. "Moghazy: Bid' hasr amlak al-ray fi al-muhafzat.” March 3, 2015. Accessed March 28, 2016. http://www.almasryalyoum.com/news/details/669418.

Alsahary, Ibrahim. "Egypt's Eave of Privatisation: What Does Sawiris Really Know?" The New Arab February 8, 2016. Accessed March 28, 2016. https:// www.alaraby.co.uk/english/Comment/2016/2/8/Egypts-wave-of-privatisationWhat-does-Sawiris-really-know.

Al-Shorouk. "Muhafiz al-Minya: Hasr aradi amlak dawla wa tashkil lagna li-alistikhdam al-amthal laha." September 30, 2015. Accessed March 28, 2016. http://www.shorouknews.com/news/view.aspx?cdate $=30092015 \mathrm{andid}=\mathrm{e} 4$ c1b572-8278-46ce-84e4-2a71ecf566d5. 


\section{Amps}

Al-Youm al-Sabe'. "Maqtal Za'eem al-Falahin al-Rafidin li-Bee'a Aradihom bilMuntazah.” September 23, 2009. Accessed January 8, 2016. http://www.youm7. com/story/0000/0/0/-/138702\#.VpA1O1J-z3U.

Beinin, Joel, and Hossam El-Hamalawy. "Egyptian Textile Workers Confront the New Economic Order." MERIP April 25, 2007. Accessed January 8, 2016. http:// www.merip.org/mero/mero032507\#[12].

Closing Conversation. City Debates 2015, American University of Beirut, March 6, 2015. Accessed January 10, 2016. https://www.youtube.com/watch?v=FS630 kcjJIQ.

Daily News Egypt. "Cotton Spinning and Weaving to Pump EGP 150m Investments into 8 Subsidiaries." September 13, 2015. Accessed January 5, 2016. http:// www.dailynewsegypt.com/2015/09/13/cotton-spinning-and-weaving-to-pumpegp-150m-investments-into-8-subsidiaries.

DeSoto, Hernando. Dead Capital and the Poor in Egypt. Cairo: ECES, 1998. Accessed January 8, 2016. http://www.eces.org.eg/Publication.aspx?Id=184.

Egypt Administrative Court. "Circuit 4; Ruling on Case 55949/66.” 2013.

Egypt Independent. "EIPR Accuses Police Officer of Murder in Nile City Incident," August 16, 2012. Accessed January 8, 2016. http://www.egyptindependent.com/ news/eipr-accuses-police-officer-murder-nile-city-incident.

Egypt News. "Wazir: Ligan li-Hasr al-'Aqarat Alati Tuskakel Khuturah 'ala Bulaq." January 2, 2011. Accessed January 8, 2016. http://www.masress.com/egynews/11 2015.

EIPR. Al-Qada' al-Idari Yantasser li Ahali al-Ramla, August 28, 2013. Accessed January 8, 2016. http://eipr.org/pressrelease/2013/08/28/1802.

EIPR. 'Ezbet al-'Arab/Muthalath al-Montazah, Internal Case Report. Cairo: EIPR, 2014.

EIPR. Mota'maret al-Mahalla, Internal Case Report. Cairo: EIPR, 2014.

ISDF. National Map of "Unsafe" Areas, Internal Report. Cairo: ISDF, 2011.

New Urban Communities Authority. Wazir al-Iskan: al-'Asema al-Idareyya al-Gadida Lan Tukalif al-Dawla Maliman Wahedan ... Wa Tarh Aradi Bi 50 Milyar Genieh al-'Am al-Muqbil, September 29, 2014. Accessed January 7, 2016. http://www. newcities.gov.eg/dispNews.aspx?ID=97.

Sada al-Balad. Infirad ... al-hukuma tasmah li-maspero bi-be'a usulh li tasdidmaduneyatuh wa amwal al-television tatahawal li milkeya khassa wa laysat milkan lil-dawla, May 13, 2015. Accessed March 28, 2016. http://www.el-balad.com/1531946.

Sejourne, Marion. "Inhabitants' Daily Practices to Obtain Legal Status for Their Homes and Security of Tenure: Egypt." In Popular Housing and Urban Land Tenure in the Middle East: Case Studies from Egypt, edited by Myriam Ababsa, Baudouin Dupret, and Eric Dennis. Cairo: American University in Cairo Press, 2012, 91-110.

Shadow Ministry of Housing. Badal Matshiluna, Tawaruna! Short documentary. 2013. Accessed January 8, 2016. https://www.youtube.com/watch?v=qrIAReY7XUI.

Shawkat, Yahia. "Al-'Adala al-Igtimaeya wal-'Omran; Kharitat Masr." Shadow Ministry of Housing. ShadowminstryOfHousing.org. 2013. Accessed January 8, 2016. http://blog.shadowministryofhousing.org/p/blog-page_2887.html. 


\section{Amps}

Shawkat, Yahia_. "Egypt's Deregulated Property Market: A Crisis of Affordability." MEI May 5, 2015. Accessed January 8, 2016. http://www.mei.edu/content/at/ egypts-deregulated-property-market-crisis-affordability.

TIMEP. Legislation Tracker: A Constitutional Perspective. n.d. Accessed October 1, 2016. http://timep.org/legislationtracker. 